\title{
Genes of Microorganisms: Paving Way to Tailor Next Generation Fungal Disease Resistant Crop Plants
}

\author{
Prem L. KASHYAPı, Gulzar S. SANGHERA², Shabir H. WANI ${ }^{3 *}$, Wajida SHAFI², Sudheer \\ KUMAR', Alok K. SRIVASTAVA', Athokpam HARIBHUSHAN ${ }^{4}$, Dilip K. ARORA ${ }^{1}$ \\ ${ }^{1}$ National Bureau of Agriculturally important Microorganisms, Kusmaur, Mau, Uttar Pradesh-275101, India \\ ${ }^{2}$ SKUAST-K, Mountain Research Centre for Field Crops, Khudwani, Anantnag, 192102, Jammu and Kashmir, India \\ ${ }^{3}$ Central Institute of Temperate Horticulture, Old air Field, Srinagar, Jammu and Kashmir, \\ India; shabirhussainwani@gmail.com (*correspondingauthor) \\ ${ }^{4}$ Krishi Vigyan Kendra, Senapati, Manipur, 795129, India
}

\begin{abstract}
The automation of sequencing technologies, flooding in the knowledge of plant-pathogen interactions and advancements in bioinformatics provide tools leading to better knowledge not only of the genome of plant pathogens or microorganism beneficial to plants but also of ways of incorporating genes from microbes into plants as microbial-derived resistance. The identification of various microorganism genes playing key role during pathogensis and the dissection of the signal transduction components of the hypersensitive response and systemic acquired resistance pathways have greatly increased the diversity of options available for tailoring fungus resistant crops. The genetically engineered plants carrying these genes showed spontaneous activation of different defense mechanisms, leading the plant in an elevated state of defense. This 'defense mode' greatly enhances the plant's ability to quickly react to a pathogen invasion and more successfully overcome the infection. The aim of this review is to highlight the dynamic use of genes of microorganisms in enhancing crop tolernace towards fungal intruders by examining the most relevant research in this field.
\end{abstract}

Keywords: genetic engineering, microorganisms, antifungal proteins, hypersensitive response, systemic acquired resistance

\section{Introduction}

The greatest challenge for the $21^{\text {st }}$ century is to provide food security to growing population of the world. Most agricultural crop species suffer from a vast array of bacteria fungal diseases which further makes the situation more tedious and complicated by enhancing annual yield loss over 12\% all over the world (Agrios, 2005; Cook, 2006). To combat losses caused by the pathogens, various crop husbandry techniques have been adopted, and the most widely used management strategy is the application of agrochemicals (Haggag, 2008; Manczinger et al., 2002). The agrochemical methods and conventional breeding commonly used to control these diseases have many drawbacks. Indiscriminate use of agrochemicals has a negative impact on human health and contributes to environmental pollution. Conventional plant-breeding strategies have limited scope due to the paucity of desirable genes with these traits inside the available gene pools and also due to their time-consuming nature.

This challenge has led agriculture sector towards gene revolution after green revolution with the help of advanced biotechnology. It has been proclaimed as third technological revolution following the industrial and computer revo- lution (Mina et al., 2008). The gene revolution of agriculture involves the understanding and modifications in the organization of traits within the genome and conversion of traits of an organism by transferring individual genes from one species to another, i.e., the creation of a transgenic organism. It has now been accepted as a method of choice for directional improvement and development of disease-resistant plants. The simplest means for engineering crops resistance to fungal diseases entails the constitutive expression of antifungal genes in transgenic plants. Transgenic plants overexpressing chitinases, $\beta-1,3$ glucanase, chitinosase and polygalacturans have been shown to exhibit enhanced levels of resistance to fungal infection and delayed disease symptoms in response to fungal invasion (Huang and Wang, 2005).

The chitinase encoding genes from plants have been used for a decade to transform a number of crops, but insufficient levels of disease resistance have been obtained (Mauch et al., 1998). Differences in levels and specificity of the antifungal chitinase activity indicate that the type and the source of the transgene are critical factors. The recent expression of fungal chitinases in plant appears to have successfully overcome the limits of plant chitinases, both in the level and the spectrum of disease resistance to fungal 
148

pathogens (Awady-El et al., 2007). This result should not be surprising since chitinases of microorganisms, especially those from mycoparasitic fungi, are optimized to break down fungal cell walls. Therefore, an approach based on constitutive over-expression of antimycolytic genes, hydrolytic enzymes and components of signaling pathways related to the defense response from microorganisms and involved in plant defence mechanisms represent a powerful and most promising strategy for conferring genetic resistance against a broad range of plant pathogenic fungi.

To date, two main strategies have been followed to express genes of microorganisms in plants to improve resistance against fungal pathogens. Disease resistant plants have been achieved by the (i) production of transgenic plants with antimycolytic compounds like proteins and toxins; (ii) generation of a hypersensitive response through avr (avirulence) genes; (iii) manipulation of genes of the SAR pathway (Systemic Acquired Resistance). This paper reviews some of the most successful instances in which genes from various microbes have been transferred to plants to improve fungal disease resistance. The potential and the use of genomes of microorganisms to genetically engineer new crop varieties with enhanced resistance traits are discussed, and some of the most promising research and microbial gene sources are presented.

\section{Engineering plants with antimycolytic molecules}

Within the scope of developing new strategies for the management of fungal infections, antifungal compounds that target essential fungal cell wall components are highly preferable. Ideally, newly developed antimycotic plants should also combine major aspects such as sustainability, high resistance, limited toxicity and low costs of production. The following sections described how various antifungal compounds of microorganism origin have been used as basic molecules to ingeneer plant crops to protect them from various fungal intruders (Tab. 1).

\section{Microorganism derived hydrolytic enzymes}

The most widely used approach of developing fungus resistant plants has been over-expression of chitinases and glucanases in transgenic plants. This is because chitin and glucan comprise major components of the cell wall of most of the fungi. Over-expression of these compounds in the plant cells is postulated to cause hyphal lysis, thereby inhibiting fungal growth (Park et al., 1996). The effectiveness of the chitinase gene of fungal origin in transgenic plants has been demonstrated by the reduced rate of lesion development and reduction of overall size and number of lesions upon challenge with pathogenic fungi (Awady-El et al., 2007). Terakawa et al. (1997), for instance, transferred chitinase encoding gene (chil) of Rhizopus oligosporus, an enzyme responsible for causing cell autolysis of the filamentous fungus to tobacco and obtained a significant level in the reduction of the foliar symptoms imposed by Sclerotinia sclerotiorum and Botrytis cinerea. Another approach was obtained by Lorito and Scala (1999) who introduced endochitinase-encoding gene of Trichoderma harzianum in tobacco and potato to achieve tolerance against a variety of phytopathogenic fungi. The transgenic expression of the T. harzianum chit 42 gene in tobacco and potato conferred almost complete resistance to Alternaria alternata, A. solani, B. cinerea, Rhizoctonia solani and $S$. sclerotiorum (Lorito et al., 1998). Interestingly, biochemical and molecular characterization of the progeny indicated that in addition to the direct antifungal effects of the transgenic chitinase, other mechanisms of the plant defence system were also activated which helped transgenics to attain high and continuous level of disease resistance. Following this successful approach, T. harzianum genes have been transferred into a variety of crops, including, apple (Bolar et al., 2000), petunia (Esposito et al., 2000), grape (Kikkert et al., 2000), broccoli (Mora and Earle, 2001), cotton (Emani et al., 2003), citrus (Distefano et al., 2008) and rice (Zhang et al., 2009). The antifungal effect against Venturia inaequalis was further enhanced by the synergistic action of a co-expressed exochitinase (Nacetylhexosaminidase) from $T$. harzianum in transgenic apple (Bolar et al., 2001). No effect of the fungal endochitinase was observed on the life cycle of the agriculturally beneficial micro-organisms including symbiotic mycorrhiza Gigantus margaritus (Lorito et al., 1993). Recently, enhanced resistance to Phoma tracheiphila and Botrytis cinerea in transgenic lemon plants expressing a Trichoderma harzianum chitinase gene (Chit 42) was obtained (Gentile et al., 2007). Similarly, transgenic carrot plants were generated by expressing CHIT36 endochitinase gene of T. harzianum in carrot plants, showing tolerance to Alternaria dauci, A. radicina and B. cinerea (Baranski et al., 2007). Later, chit1 gene encoding endochitinase CHIT42 from the entomopathogenic fungus Metarhizium anisopliae was engineered in tobacco plants to achieve resistance against Rhizoctonia solani (Kern et al., 2010).

Although, chitinase genes of bacterial origin have not been used extensively to engineer plants. This may be because they are exochitanases and presumed to be less active against fungi (Roberts and Selitrennikoff, 1998). The first attempts to use a bacterial origin chitinase gene to enhance plant defence were made by using $\operatorname{chi} A$ from Serratia marcescens. Jones et al. (1988) and Suslow et al. (1988) transferred the chitinase gene of $S$. marcescens into tobacco; the transgenic plants exhibited elevated chitinase activity and increased resistance to Aspergillus longipes. Later, Howie et al. (1994) found that the same gene provided tolerance to $R$. solani in the field. The protective role of bacterial chitinases was also confirmed by Toyoda et al. (1991) who injected chitinase from Streptomyces griseus into barley epidermis cells, and found that the enzyme digested the haustoria of Erysiphe graminis, the powdery mildew pathogen. Moreover, a bacterial family (Chitinase $\mathrm{ChiC}$ ) from Streptomyces griseus showed evident inhibi- 
Tab. 1. Exploitation of microorganism genes for the enhancement of resistance against fungal pathogens

\begin{tabular}{|c|c|c|c|c|}
\hline Microorganism & Gene/gene product & Target pathogen & Recipient host & References \\
\hline \multicolumn{5}{|c|}{ Hydrolytic enzymes } \\
\hline Metarbizium anisopliae & chit1 / endochitinase CHIT42 & Rhizoctonia solani & Tobacco & Kern et al., 2010 \\
\hline \multirow[t]{7}{*}{ Trichoderma harzianum } & Th-Chit / Trichoderma chitinase & Alternaria alternata & Tobacco & Saiprasad et al., 2009 \\
\hline & CHIT36/ endochitinase CHIT36 & Alternaria dauci & Carrot & Baranski et al., 2008 \\
\hline & endochitinase gene & Rhizctonia solani & Cotton & Emani, et al., 2003 \\
\hline & $\begin{array}{c}\text { CHIT33 and CHIT42/ } \\
\text { endochitinases CHIT33 } \\
\text { and CHIT42 }\end{array}$ & $\begin{array}{l}\text { Pseudomonas syringae pv. tabaci } \\
\text { and Rhizoctonia solani } \mathrm{pv} \text {. tabaci }\end{array}$ & Tobacco & Dana et al., 2006 \\
\hline & Endochitinase, Exochitinase & Venturia inequalis & Apple & Bolar et al.,2001 \\
\hline & Endochitinase & Botrytis cinerea & Grape & Kikkert et al., 2000 \\
\hline & Endochitinase & $\begin{array}{l}\text { Foliar and soil borne } \\
\text { fungal pathogen }\end{array}$ & Potato & Lorito et al., 1998 \\
\hline T. atroviridae & ech42, nag 70, gluc 78 & Magnaporthe grisea & Rice & Liu et al., 2004 \\
\hline Streptomyces griseus & Chitinase $C($ Chi $C)$ & Magnaporthe grisea & Rice & Itoh et al., 2003 \\
\hline \multicolumn{5}{|c|}{$\begin{array}{l}\text { Polygalacturonase inhibitor proteins } \\
\end{array}$} \\
\hline Aspergillus niger & PGII & B. cinerea & $\begin{array}{c}\text { Tobacco and } \\
\text { Arabidopsis thaliana }\end{array}$ & Ferrari et al., 2008 \\
\hline \multicolumn{5}{|c|}{ Antifungal peptides } \\
\hline Aspergillus giganteus & $A f p$ & Rust and Downy mildew & Pearl millet & Girgji et al., 2006 \\
\hline A. giganteus & $A F P$ & Magnaporthe grisea & Rice & $\begin{array}{l}\text { Coca et al., 2004, } \\
\text { Moreno et al., } 2005 .\end{array}$ \\
\hline \multicolumn{5}{|c|}{ Mycotoxins } \\
\hline B. thuringiensis & $\operatorname{Cry} 1 \mathrm{Ab}$ & Fusarium spp. & Zea mays & Hammond et al., 2004 \\
\hline Fusarium spp. & $\begin{array}{l}\text { Fusarium specific antibody } \\
\text { linked to antifungal peptides }\end{array}$ & $\begin{array}{l}\text { Fusarium oxysporum } \\
\text { f.sp. matthiolae }\end{array}$ & Arabidopsis & Peschen et al., 2004 \\
\hline \multicolumn{5}{|c|}{ Elicitors } \\
\hline Phytophthora cryptogea & $\beta$-cryptogein elicitor & $\begin{array}{l}\text { Phytophthora } \\
\text { parasitica }\end{array}$ & Tobacco & Keller et al.,1999 \\
\hline A. niger & glucose oxidase gene & $\begin{array}{l}\text { Phytophthora } \\
\text { infestans Alternaria solani } \\
\text { and Verticillium dabliae }\end{array}$ & Potato & Kachroo et al., 2003 \\
\hline Pseudomonas pyrrocinia & cpo-p/ chloroperoxidase & Aspergillus flavus & Peanut & Tepfer et al., 1998 \\
\hline Pseudomonas fluorescence & Microbial factor 3 (MF3) & $\begin{array}{l}\text { Alternaria dauci, } \\
\text { Alternaria radicina } \\
\text { and Botrytis cinerea }\end{array}$ & Carrot & Baranski et al., 2007 \\
\hline Pseudomonas aeruginosa & katE /Catalase & $\begin{array}{l}\text { Peronospora parasitica } \\
\text { and Erysiphe polygoni }\end{array}$ & Canola & Awady-El et al., 2007 \\
\hline Pseudomonas spp. & Chloroperoxidase & Colletotrichum destructivum & Tobacco & Niu et al., 2009 \\
\hline Bacterial origin & Salicylic acid synthase & Oidium lycopersicon & Tobacco & Rajasekaran et al., 2000 \\
\hline \multicolumn{5}{|c|}{ Harpin proteins } \\
\hline Erwinia pyrifoliae & $\operatorname{brp} N_{E I} /$ Harpin & Botrytis cinerea & Tobacco & Takakura et al., 2008 \\
\hline Ralstonia solanacearum & popA & $\begin{array}{l}\text { Phytophthora parasitica } \\
\text { var. nicotianae }\end{array}$ & Tobacco & Miao et al., 2010 \\
\hline $\begin{array}{l}\text { Xanthomonas } \\
\text { oryzae pv. oryzae }\end{array}$ & hpal $_{X \circ o}$ & Magnaporthe grisea & Rice & Malnoy et al.,2005 \\
\hline X. oryzae pv. oryzae & hpal $_{X a 0}$ & Verticillium dablia & Cotton & Shao et al.,2008 \\
\hline \multicolumn{5}{|c|}{ Ion fluxes } \\
\hline Halobacterium halobium & $\mathrm{bO}$ & P. infestans & Tobacco & Mourgues et al.,1998 \\
\hline \multicolumn{5}{|c|}{ Barnase- barstar system } \\
\hline Bacillus amyloliquefaciens & RNAse & P. infestans & Potato & Strittmatter et al.,1995 \\
\hline B. amyloliquefaciens & RNAse & Magnaporthe grisea & Rice & Esfahani et al.,2010 \\
\hline \multicolumn{5}{|c|}{ Antimycolytic gene pyramiding } \\
\hline $\begin{array}{l}\text { Trichoderma atroviride } \\
\text { and T. virens }\end{array}$ & chit42 + bgn13.1 & Rhizoctonia solani & Potato & Esfahani et al., 2010 \\
\hline
\end{tabular}


150

tion on fungal hyphal extension in vitro. Ninety percent of transgenic rice plants expressing $C h i C$ had higher resistance against Magnaporthe grisea than non-transgenic plants (Itoh et al., 2003).

\section{Antifungal peptides (AFP)}

Antifungal peptides (AFP) are cationic molecules, with a net of positive charge, and ubiquitously switched-on the plant defense system by binding to pathogen membranes, which are generally negatively charged (Zasloff, 2002). A naturally derived molecule that possesses all these desired characteristics is the antifungal protein (AFP) secreted by the filamentous ascomycete Aspergillus giganteus which is a powerful antimycotic against various plant pathogens including Magnaporthe grisea, Botrytis cinerea, Fusarium oxysporum and several others which have been well documented in literature (Meyer, 2008). Caco et al. (2004) showed that rice plants can be engineered for resistance against the blast fungus ( $M$. grisea) by expression of the $A$. giganteus afp gene under the control of the constitutive maize ubiquitin promoter. Transgenic rice constitutively expressing AFP protein showed inheritance of the transgene without any effect on plant morphology, growth and development (Moreno et al., 2005). Recently, rust and downy mildew resistance in pearl millet (Pennisetum glaucum) was achieved by heterologous expression of the afp gene from Aspergillus giganteus through particle bombardment of immature zygotic embryos (Girgji et al., 2006). However, examples of antifungal peptides from microorganism origin expressed in plants are still scarces and one of the unexplored niches.

\section{Polygalacturonase inbibitor proteins (PGIPs)}

Polygalacturonase-inhibiting proteins (PGIPs) are plant cell wall proteins that protect plants from fungal invasion. They interact with endo-polygalacturonases secreted by phytopathogenic fungi through the inhibition of their enzymatic activity, and favor the accumulation of oligogalacturonides, which activate plant defense responses (Federici et al., 2006). Partial degradation of homogalacturonan (HGA) by fungal endo-polygalacturonases (PGs), for instance, releases oligogalacturonides (OGs) which are regarded as host-associated molecular patterns for regulation of plant innate immunity (Stern et al., 2006). Working on these lines Ferrari et al. (2008) generated transgenic plants by expressing Aspergillus niger PGII into tobacco and Arabidopsis thaliana to enhance the level of protection of plants against $B$. cinerea. We believe that this line of research will provide new insights in the regulation of plant defense responses during plant-pathogen interactions.

\section{Mycotoxins}

Production of secondary metabolites, such as mycotoxins and oxalic acid by fungi has been shown to facilitate infections in host tissues followed by programmed cell death. Degradation of these compounds by enzymes expressed in the transgenic plants could provide an opportunity to enhance resistance against diseases. A limited number of toxins derived from fungi or bacteria have been transgenically expressed in plants increasing disease resistance. The most successful case is the expression of trichothecene-degrading enzymes from Fusarium sporotrichioides in tobacco. The generated plants showed reduced plant tissue damages and enhanced seedling emergence in presence of trichothecene (Muhitch and McCormick, 2000). Later on, transgenic maize was developed by using this strategy and it was found a $10 \%$ of reduction in the levels of the Fusarium-toxin zearalerone as compared to wild-type plants (Igawa et al., 2007). Transgenic tobacco plants carrying and expressing the toxin of Ustilago maydis KP4 killer gene had already been reported by Park et al. (1996). These toxins are actually encoded by the dsRNA of the $U$. maydis virus $(U m V)$ which persistently infects the fungus, and provides a selective advantage to the host cell by killing other $U$. maydis strains. Afterward, Clausen et al. (2000) demonstrated the over expression of this toxin in transgenic wheat associated with antifungal activity against $U$. maydis and Tilletia tritici. In a greenhouse test, the transgenic wheat plants did not exert any measurable injurious effect on soil microarthropod populations after evaluation of different parameters in a feeding bioassay (Romeis et al., 2003). If these letal toxins are efficient against a broader range of plant pathogenic fungi, they could be a novel means for disease control.

Another mycotoxin is the oxalic acid which has an important role as a toxic pathogenicity factor in several species of necrotrophs, of which Sclerotinia sclerotiorum is a particular problem in many dicotyledonous species, for example, oilseed rape (Brassica napus) and sunflower (Helianthus annuus). Several studies have therefore taken the approach of constitutively expressing a heterologous (usually wheat) oxalate oxidase gene in a target crop in order to neutralize the oxalic acid produced by the pathogen. The products of the enzyme include the reactive oxygen species hydrogen peroxide, which itself has an important role in disease resistance (Shetty et al., 2007). Examples where partial resistance has been obtained in the laboratory include sunflower and soybean (Glycine max) against Sclerotinia sclerotiorum (Cober et al., 2003; Donaldson et al., 2001; Hu et al., 2003) as well as poplar (Populus $\times$ euramericana) against Septoria musiva (Liang et al., 2004).

\section{Transgenics engineered for hypersensitive response (HR)}

After perceiving the avr gene product, the elicitors, signal cascade is trigger by activation of host activator molecules. These activator molecules then interact with signal molecules such as $\mathrm{H}_{2} \mathrm{O}_{2}$, salicylic acid (SA), jasmonic acid (JA) and ethylene thereby triggering defense responses in plants, exemplified by HR, PR proteins and phytoalexin (Hain et al., 1993). 
Ion fluxes

Ion fluxes are one of the early events in incompatible plant pathogen interactions. Therefore, changes in proton translocation by altered expression of proton pumps can lead to SAR-like defense responses even without pathogen infection. The successful example that exploits such type of approach to engineer plants is based on the expression of a bacterial gene $(b O)$ encoding a proton pump, the bacterio-opsin, derived from Halobacterium halobium. The constitutive expression of $b O$ gene in potato plants produces a lesion mimic phenotype in which necrotic lesions are displayed and local and systemic defence responses are activated in the absence of pathogens. Tobacco plants expressing $b O$ had increased levels of salicylic acid and were more resistant to $P$. infestans isolates showing A1 mating type (Mourgues et al., 1998).

\section{Hydrogen peroxide}

Hydrogen peroxide $\left(\mathrm{H}_{2} \mathrm{O}_{2}\right)$ is one of the activator molecules which interacts with a signal cascade exerting direct antimicrobial activity, diffusing the signal for activation of cellular defence genes and reinforcing the plant cell wall (Shetty et al., 2008). The direct evidence that ROS (Reactive Oxygen Species) are involved conferring plant disease resistance was provided by the constitutive expression of glucose-oxidase gene ( $G O X)$ from Aspergillus niger in transgenic potato. Wu et al. (1995) reported that the introduction of GOX gene in potato caused delayed lesion development by Phytophthora infestans and reduced disease development by Alternaria solani and Verticillium dabliae. Enhanced resistance of transgenic rice plants to $M$. grisea was also demonstrated and it is correlated with constitutive and pathogen-induced expression of an Aspergillus niger $G O X$ gene, responsible for elevating the endogenous levels of $\mathrm{H}_{2} \mathrm{O}_{2}$ which in turn caused typical cell death and activated the expression of several defense genes (Kachroo et al., 2003). However, it should be done with caution since high levels of $\mathrm{H}_{2} \mathrm{O}_{2}$ in transgenic plants may cause metabolic disturbances interfering with normal growth and development. Using pathogen-inducible expression of $\mathrm{H}_{2} \mathrm{O}_{2}$ generating genes may be an effective way to confer broad-spectrum resistance in rice without the penalty of causing any developmental abnormalities or metabolic errors. Thus, the expression of $\mathrm{H}_{2} \mathrm{O}_{2}$ generating enzymes of fungal origin in transgenic plants represents a novel strategy for engineering broad-spectrum resistance to fungal pathogens.

Certain bacteria, such as Escherichia coli and Pseudomonas fluorescence, have well-characterized pathways for the production of salicylic acid. In $E$. coli, the ent $C$ gene encodes the enzyme isochorismate isomerase, which converts chorismic acid to salicylic acid, while in P. fuorescence, the $p m s B$ gene encodes pyruvate lyase, which converts isochorismic acid into salicylic acid. Verberne et al. (2000) developed transgenic tobacco plants that constitutively expressed both ent $C$ and $p m s B$ in the chloroplast. The transgenic tobacco plants expressing these genes showed accumulation of salicylic acid that were up to 1000 times higher than in wild-type tobacco. When exposed to the fungus Oidium lycopersicon, the transgenic tobacco plants showed increased levels of resistance when compared to the wild-type plants. The transgenic plants did not show any adverse effects due to the high level expression of salicylic acid. Since the role of salicylic acid in triggering SAR against a variety of pathogens is believed to be similar for all higher plants, the same strategy used in this research can be applied to other commercially important crops to enhance their resistance to different pathogens. Rajasekaran et al. (2000) reported that the expression of a chloroperoxidase gene from Pseudomonas pyrrocinia (cpo-p) in transgenic tobacco resulted in significant inhibition of Aspergillus flavus hyphal growth and reduced leaf anthracnose lesions caused by Colletotrichum destructivum. Recently, Niu et al. (2009) also demonstrated the successful insertion and expression of the cpo-p gene derived from Pseudomonas pyrrocinia into the groundnut Arachis bypogaea. The developed transgenic groundnut plants showed inhibition of Aspergillus flavus hyphal growth, which resulted in the reduction of aflatoxin contamination in peanut seeds.

\section{Elicitors}

Disease resistance responses caused by elicitors other than the products of avirulence genes have been also used to increase plant resistance to pathogens. Tobacco plants were transformed by a PHytophthora cryptogea gene encoding the elicitor protein cryptogein under the control of the constitutive $35 \mathrm{~S}$ cauliflower mosaic virus (CaMV) promoter and the nos terminator (Tepfer et al., 1998). The transformed plants exhibited resistance to $P$. parasitica var. nicotianae which does not secrete elicitins and is normally pathogenic to tobacco. Cryptogein accumulates into the cells and may be liberated upon fungal infection. Tobacco also has been transformed with cryptogein under the control of the pathogen inducible tobacco hsr 203J gene promoter (Keller et al., 1999). The transgene which was silent in the absence of the pathogen, was activated upon infection by $P$. parasitica var. nicotianae, producing cryptogein around the infection sites and subsequently elicitating a hypersensitive response (HR), leading to resistance. Such transgenic plants were also more resistant to other fungal pathogens such as Thielaviopsis basicola, Erysiphe cichoracearum, and $B$. cinerea.

Elicitor produced by Cladosporium fulvum is a product of virulence gene 'avr9' and De Wit (1992) proposed that if 'avr9' gene can be introduced, then a broad spectrum resistance could be obtained. Hammond et al. (2004) showed HR response in tomato seedlings by expression of the 'avr9' transgene. Transgenic tobacco plants were made harboring a fusion between the pathogen-inducible tobacco 'hsr203J' gene promoter and Phytophthora cryptogea gene encoding elicitor cryptogene in order to control 
152

the expression of 'avr9' gene only in presence of pathogen (Keller et al., 1999). They reported a strict cryptogene expression, i.e., HR response was tightly controlled and observed only in presence of $P$. parasitica var. nicotianae. Moreover, the transgenic plants displayed enhanced resistance to few other unrelated species, such as Thielaviopsis basicola, Erysiphe cichoracearum and Botrytis cinerea. This report not only demonstrated that single gene could produce a broad spectrum resistance, but also implied that when a gene was introduced into heterologous system the effectiveness of the gene had to be assessed very cautiously since the introduced gene may cause resistance towards many more untargeted non-related species. Recently, Qiu et al. (2009) isolated an elicitor-encoding gene (pemG1) from Magnaporthe grisea, the rice blast fungus, and introduced into rice (Oryza sativa L. cv. 'Nipponbare') under the constitutive control of maize ubiquitin promoter. The pemG1-expressing plants showed enhanced resistance against the fungus suggesting that the elicitor-encoding gene could be a novel approach to enhance disease resistance in various crops.

\section{Harpin proteins}

Harpin group of proteins stimulate plant growth and pathogen defense. The proteins contain a characteristic hairpin and are are glycine-rich, protease-sensitive, heatstable, and very often are produced by Gram negative plant pathogenic bacteria. They also induce hypersensitive cell death (HCD) in non-host plants of bacteria by activating SAR pathway. To date, a few harpins or harpin-like proteins, such as hrpZ $\mathrm{P}_{\mathrm{Ps}}$ from Pseudomonas syringae pv. syringae (He et al., 1993), hrpN $\mathrm{Ea}_{\mathrm{a}}$ from Erwinia amylovora (Kim and Beer, 1998) and hpal ${ }_{\text {Xoo }}$ from Xanthomonas oryzae pv. oryzae (Peng et al., 2004) have been characterized. The feasible use of these harpin protein genes from various infection-induced HR, as a new strategy of engineering fungal disease resistance was explored (Li et al., 1999) and a transgenic potato showing enhanced level pf resistance towards Phytophthora infestans was first developed using a harpin protein gene from Erwinia amylovora and potato prp1-1 promoter as main DNA elements. Belbahri et al. (2001) used the $р о p A$ gene from the phytopathogenic bacterium Ralstonia solanacearum showing sequence similarity with $\mathrm{Hpa}_{\text {Xoo }}$ to develop transgenic tobacco plants resistant to Phytophthora parasitica var. nicotianae under the control of the hypersensitivity-related plant promoter hsr203J. The developed plants accumulating the PopA protein showed localized HR and increased resistance to $P$. parasitica. Recently, Miao et al. (2010) showed that the transformation of $h p a 1_{X o o}$ into cotton conferred the improved resistance to Verticillium dablia in the transgenic cotton. Similarly, a high level of resistance to all predominant races of Magnaporthe grisea in China was obtained in the rice line transformed with hpal $1_{\text {Xoo }}$ from Xanthomonas oryzae pv. oryzae (Shao et al., 2008). Several other hrp genes isolated have also been successfully transformed into different plant species including pear (Malnoy et al., 2005) and tobacco (Sohn et al., 2007). These results highlighted that engineered harpins of phytopathogenic bacteria in plants was a very promising approach to produce fungal disease resistant genotype. Unfortunately, the defense responses elicited by harpins and their active sites in hosts have not been fully understood yet and need to be dissected in future to harness their real potential in plant engineering.

\section{Flagellin proteins}

Microbe-derived molecules such as bacterial flagellin and lipopolysaccharides, collectively called pathogen associated molecular patterns (PAMPs) or microbe-associated molecular patterns (MAMPs) trigger immunity in plants. The flagellin gene from a phytopathogenic bacterium, Acidovorax avenae strain N1141, was introduced into rice and the resultant transgenic rice plants accumulated flagellin at various levels. The transgenic plants showed increased expression of defense genes, $\mathrm{H}_{2} \mathrm{O}_{2}$ production and cell death, suggesting that the flagellin triggers innate immune responses in the transgenic rice. When rice plants were inoculated with $M$. grisea, the transgenics exhibited enhanced resistance, suggesting that the flagellin approach might provide a new strategy for developing genetically engineered disease-resistant rice varieties (Takakura et al., 2008).

\section{Two component pathogen sensory system}

\section{Resistance gene-avirulence gene system}

Genes that may protect plants by activating defence responses or inhibiting pathogen virulence factors have also been exploited in engineering resistance. Avirulence genes $(A v r)$ in pathogens and their matching resistance $(R)$ genes in host plants have received considerable attention (Kiraly and Hornok, 1997). In plant-pathogen systems following the gene for gene relationship, the interactions between the product of an Avr gene (elicitor) and the product of the corresponding $R$ gene (receptor) activate a signal transduction pathway which leads to resistance, often through a hypersensitive response (HR). Several Avr and $R$ genes have been cloned and the Avr/R gene pair has been transferred in plants to engineer resistance (Honée et al., 1997), particularly, following De Wit's introduction of the two component sensor system method (Hammond et al., 2004). The avirulence gene Avr9 of Cladosporium fulvum and its matching resistance gene $C f 9$ were the first pair to be used in this strategy. Constructs were made fusing either the $A v r 9$ or the $C f 9$ gene with the infection site specific promoter Pgst1 of a potato defence gene (Strittmatter et al., 1995), then transferred to tomato. Several tomato transgenic lines were identified which showed resistance to a wild type Avr9-strain of $C$. fulvum by inducing the $\mathrm{HR}$ at the infection sites. In one case ECP2, a virulence factor secreted by $C$. cladosporium which is required for full virulence on tomato, proved to be useful for re- 
sistance engineering. These plants recognized specifically C. fulvum strains producing ECP2 and became resistant through induction of HR (Lauge et al., 1998). However, since $C f-E C P 2$ induces HR by recognizing an important virulence factor, it is conceivable that it may represent a durable source of resistance. This result suggests that a targeted search for HR may be of great value to discover new genes able to confer resistance, also against pathogens involved in other plant/pathogen systems. Moreover, to avoid unwanted expression of Avr/R, which leads to generalized HR and consequently plant death, one of the genes must be regulated by a pathogen inducible promoter.

\section{Barnase-barstar system}

Several systems have been tested to mimic HR in transgenic plants as a mechanism of localized cell death and resistance to pathogen. Although this approach has the potential to provide a broad spectrum resistance to bacteria, fungi and viruses, it requires the use of specific promoters to restrict the effect of the transgene at the site of infection in order to avoid a deleterious generalized HR response and plant death. An interesting strategy has been applied by Strittmatter $e$ al. (1995), who expressed in plant a bacterial ribonuclease gene (barnase) driven by a pathogen inducible promoter from potato ( $\operatorname{prp} 1-1)$. They also transferred to the transgenic potato a gene coding for an inhibitor of barnase activity (barnstar) to reduce detrimental effects of background activity of ribonuclease (RNase) on the non-infected tissues. When the potato progenies were challenged with $P$. infestans a strong barnase activity was induced only at the infection site, with a significantly decrease. This strategy, however, was not tested at the field level. The strategy of the two-component system, was further adopted by Shengji et al. (2003) to obtain transgenic rice resistant to Magnaporthe grisea. In this study, two chimeric promoters, induced by rice blast fungus pathogen (Magnaporthe grisea), are fused with Barnase respectively to construct two plant expression vectors, pWBNBS and pPBNBS together with the Barstar driven by CaMV 355 promoter. The expression of Barnase is induced in rice leaves when inoculated with the spores of Magnaporthe grisea and the transgenic plant shows high levels of resistance to the rice fungal blast disease. These results suggest that transgenic plants harboring this two-component system may be exploited to acquire relatively broad spectrum and elevated resistance against fungal pathogen in various other agriculturally important crops.

\section{Antimycolytic gene pyramiding}

The resistance in newly released varieties can be lost quickly due to the high level of instability in the pathogen population. The best approach to circumvent this problem is to re-engenniering plants with multiple resistant microbial transgenes showing different mechanisms which could enlarge the spectrum and enhance the level of resistance in transgenic crops. This approach was first time adopted by Lorito et al. (1998), where they constructed a transgene containing chitinases and $\beta$ - 1,3 -glucanases from Trichoderma sp. and achieved strong and highly synergistic in combination antifungal activities against various fungal pathogens. Recently, Esfahani et al. (2010), used chitinase gene (chit42) from Trichoderma atroviride and the $\beta$-1, 3-glucanase gene (bgn13.1) from Trichoderma virens to prepare a double gene construct containing these two genes. The transformed potato (Solanum tuberosum cv. Savalan) showed enhanced resistance to Rbizoctonia solani AG-3, responsible for causing stem and root rot diseases.

\section{Challenge ahead}

All the strategies mentioned above concentrate on introduction and over expression of antimycolytic genes to make transgenic plants to combat fungal infection. In most of the cases the antifungal genes have been introduced under constitutive expression resulting in the continuous expression of transgenes. So, the ultimate success of a transgenic plant to inhibit fungal infection depends on the expression level of the transgene(s) introduced in it. However, the expression of foreign genes in plants have also recorded numerous problems and defeats often because the genetically engineered plants failed to produce the desired gene product at the expected level, even though plant promoters were used, or the transgenic protein significantly affected plant growth and development (Hain et al., 1993). Under constitutive promoter CaMV35S, transgenic tomato was also reported to die when transformed with elicitor gene 'avr 9 ' to produce fungal resistant plants (Honée et al., 1997). Although $\mathrm{T}_{0}$ generation was morphologically normal, Anand et al. (2003), reported necrotic lesions containing dead cells in $\mathrm{T}_{2}$ and subsequent generations, when the wheat transgenic lines were homozygous for the transgenes (co-expression of chitinase and glucanase). In contrast, lesions were not observed in hemizygous transgenic lines or lines silenced for transgene expression, indicating a requirement for high levels of transgene expression for the development of the lesioned phenotype. It is therefore imperative that emphasis is directed to express transgenes at a level effective for fungal inhibition.

In the light of these observations, attempts are now made to develop transgenic plants with regulated or tissue-specific expression of transgenes in order to avoid such deleterious effects of putatively harmful transgene products as well as to minimize the loss of efforts due to continuous production of transgene products. The use of pathogen-inducible promoter is the best option to tightly control the expression of transgene. Keller et al. (1999), developed transgenic tobacco plants harbouring a fusioned product between the pathogen-inducible tobacco ' $h s r 2035$ ' gene promoter in combination with cryptogene 
154

elicitor encoded by Phytophthora cryptogea. The transgenic tobacco plants regenerated with this homologous pathogen-inducible promoter were reported to have tightly controlled expression of the transgene only in presence of the pathogen.

\section{Conclusions}

Recent advances in the investigation field of microorganism genome, molecular biology and transgenic technologies have enabled the plant tailors to know more about the elegant features of genes available within microorganism which require special attention. Exploitation of these genes for the crop improvement could be considered as the 'powerful seeds' that will solve the problems of $21^{\text {st }}$ century arising from various fungal infections. Further, large scale field trials are needed to test whether expression of the introduced microbial genes will affect yields, quality, or agronomic traits. Although the introduced microbial genes are well-defined, the field trials also provide the opportunity to ascertain whether any unexpected or undesirable consequences have resulted from the transformation procedure. Genetically engineered crops by using microbial genes are just beginning to make their way into the hands of crop engineers. When carefully set up microbe genome will become an integral supplement to modern biotechnology and its enormous potential should be harnessed to the best advantage of the entire human beings. Moreover, several of the biosafety and related environmental and food safety concerns associated with the cultivation of and trade in transgenic crops remain relevant and thus appropriate policies and strategies to safeguard against potential adverse effects are require.

\section{References}

Agrios GN (2005). Plant Pathology, Fifth Edition. Elsevier Academic Press, $514 \mathrm{p}$.

Anand A, Zhou T, Trick HN, Gill BS, Bockus WW, Muthukrishnan S (2003). Greenhouse and field testing of transgenic wheat plants stably expressing genes for thaumatin-like protein, chitinase and glucanase against Fusarium graminearum. J Exp Bot 54:1101-1111.

Awady-El M, Reda EA, Moghaieb EA, Haggag W, Youssef SS, El-Sharkawy AM (2007). Transgenic canola plants overexpressing bacterial catalase exhibit enhanced resistance to Peronospora parasitica and Erysiphe polygoni. Arab J Biotechnol 11:71-84.

Baranski R, Klocke E, Nothnagel T (2007). Enhancing resistance of transgenic carrot to fungal pathogens by the expression of Pseudomonas fluorescence microbial factor 3 (MF3) gene. Physiol Mol Plant Pathol 71:88-95.

Belbahri L, Boucher C, Candresse T, Nicole M, Ricci P, Keller H (2001). A local accumulation of the Ralstonia solanacearum PopA protein in transgenic tobacco renders a compatible plant-pathogen interaction incompatible. Plant J 28:419430.

Bolar JP, Norelli JL, Wong KW, Hayes CK, Harman GE, Aldwinkle HS (2000). Expression of endochitinase from Trichoderma harzianum in transgenic apple increases resistance to apple scab and reduces vigor. Phytopathol 90:72-77.

Bolar JP, Norelli JL, Harman GE, Brown SK, Aldwinkle HS (2001).Synergistic activity of endochitinase and exochitinase from Trichoderma atroviride ( $T$. harzianum) against the pathogenic fungus (Venturia inaequalis) in transgenic apple plants. Transgen Res 10:533-543.

Clausen M, Kräuter R, Schachermayr G, Potrykus I, Sautter C (2000). Antifungal activity of a virally encoded gene in transgenic wheat. Nat Biotechnol 18:446-449.

Cober ER, Rioux S, Rajcan I, Donaldson PA, Simmonds DH (2003). Partial resistance to white mold in a transgenic soybean line. Crop Sci 43:92-95.

Coca M, Bortolotti C, Rufat M, Peñas G, Eritja R, Tharreau D, del Pozo AM, Messeguer J, Sansegundo B (2004). Transgenic rice plants expressing the antifungal AFP protein from Aspergillus giganteus show enhanced resistance to the rice blast fungus Magnaporthe grisea. Plant Mol Biol 54:245259.

Cook J (2006). Towards cropping systems that enhance productivity and sustainability. Proc Natl Acad Sci USA 103:18389-18394.

Dana MM, Pintor-Toro JA, Cubero B (2006). Transgenic tobacco plants over expressing chitinases of fungal origin show enhanced resistance to biotic and abiotic stress agents. Plant Physiol 142:722-730.

De Wit PJGM (1992). Molecular characterization of gene-forgene systems in plant fungus interactions and the applications of a virulence genes in control of plant pathogens. Ann Rev Phytopathol 30:391-418.

Distefano G, Malfa SL, Vitale A, Lorito M, Deng Z, Gentile A (2008). Defence-related gene expression in transgenic lemon plants producing an antimicrobial Trichoderma harzianum endochitinase during fungal infection. Transgen Res 17:873-879.

Donaldson E, Schillinger WF, Stephen MD (2001). Straw production and grain yield relationships in winter wheat. Crop Sci 41:100-106.

Emani C, Garcia JM, Lopata-Finch E, Pozo MJ, Uribe P, Kim DJ, Kumar SG, Cook DR, Kenerley CM, Rathore KS (2003). Enhanced fungal resistance in transgenic cotton expressing an endochitinase gene from Trichoderma virens. J Plant Biotechnol 1:321-336

Esfahani SN, Shahhosseiny MH, Yaghmai P, Praivar K, Moslemi E, Amini HK (2010). Rapid and simple detection of Hepatitis $\mathrm{C}$ virus by reverse transcriptase -loop- mediated isothermal amplification method. Afric J Microbiol Res 4:2580-2586. 
Esposito S, Colucci MG, Frusciante L, Fillippone E, Lorito M, Bressan RA (2000). Antifungal transgenes expression in Petunia hybrid. Acta Hort 508:157-161.

Federici L, Matteo AD, Fernandez-Recio J, Tsernoglou D, Cervon F (2006). Polygalacturonase inhibiting proteins: players in plant innate immunity. Trends Plant Sci 11:6570.

Ferrari S, Galletti R, Pontiggia D, Manfredini C, Lionetti V, Bellincampi D, Cervone F, Lorenzo GD (2008). Transgenic expression of a fungal endo-polygalacturonase increases plant resistance to pathogens and reduces auxin sensitivity. Plant Physiol 146:669-681.

Gentile A, Deng Z, La Malfa S (2007). Enhanced resistance to Phoma tracheiphila and Botrytis cinerea in transgenic lemon plants expressing a Trichoderma harzianum chitinase gene. Plant Breed 126:146-151.

Girgji M, Breese WA, Lörz H, Oldach KH (2006). Rust and downy mildew resistance in pearl millet (Pennisetum glaucum) mediated by heterologous expression of the afp gene from Aspergillus giganteus. Transgen Res 15:313-324.

Haggag WM (2008). Biotechnological aspects of plant resistant for fungal diseases management. Am Eurasian J Sustain Agric 2:1-18.

Hain R, Reif HJ, Krause E, Langebartels R, Kindl H, Vornam B, Wiese W, Schmelzer E, Schreier P, Stöcker R, Stenzel K (1993). Disease resistance results from foreign phytoalexin expression in a novel plant. Nature 361:153-156.

Hammond BG, Campbell KW, Pilcher CD, Degooyer TA, Robinson AE, McMillen BL, Spangler SM, Riordan SG, Rice LG, Richard JL (2004). Lower fumonisin mycotoxin levels in the grain of Bt corn grown in the United States in 2000-2002. J Agric Food Chem 52:1390-1397.

He SY, Huang HC, Collmer A (1993). Pseudomonas syringae pv. Syringae harpinPss.: a protein that is secreted via the Hrp pathway and elicits the hypersensitive response in plants. Cell 73:1255-1266.

Honée G, Stuiver M, Weide R, Tigelaar H, Melchers LS, De Wit PJGM (1997). Infection induced expression of the avirulence gene Avr 9 in transgenic CF9 tomato plants confers resistance to fungal pathogen attack. In: Dean JFD (Ed.). $5^{\text {th }}$ International Congress of Plant Molecular Biology, Singapore 15 3, Plant Molecular Biology Reporter, Kluwer Academic.

Howie W, Joe L, Newbigin E, Suslow TV, Dunsmuir P (1994). Transgenic tobacco plants which express the chiA gene from Serratia marcescens have enhanced tolerance to Rhizoctonia solani. Transgen Res 3:90-98.

Hu X, Bidney DL, Yalpani N, Duvick JP, Crasta O (2003). Over expression of a gene encoding hydrogen peroxide-generating oxalate oxidase evokes defense responses in sunflower. Plant Physiol 133:170-181.

Huang CJ, Wang TK (2005). Identification of an antifungal chitinase from a potential biocontrol agent. Bacillus cereus 28-9. J Biochem Mol Biol Sci 38:82-88.
Igawa T, Takahashi-Ando N, Ochiai N, Ohsato S, Shimizu T, Kudo T, Yamaguchi I, Kimura M (2007). Reduced contamination by the Fusarium mycotoxin zearalenone in maize kernels through genetic modification with a detoxification gene. Appl Environ Microbiol 73:16221629.

Itoh Y, Takahashi K, Takizawa H, Nikaidou N, Tanaka H, Nishihashi H, Watanabe T, Nishizawa Y (2003). Family 19 chitinase of Streptomyces griseus HUT6037 increases plant resistance to the fungal disease. Biosc Biotechnol Biochem 67:847-855.

Jones JDG, Dean C, Gidoni D, Gilbert D, Bon-Nutter D, Lee R, Bedbrook J (1988). Expression of bacterial chitinase protein in tobacco leaves using two photosynthetic gene promoters. Mol Gen Genet 212 536-542.

Kachroo A, He Z, Patkar R, Zhu Q, Zhong J, Li D, Ronald P, Lamb C, Chattoo BB (2003). Induction of $\mathrm{H}_{2} \mathrm{O}_{2}$ in transgenic rice leads to cell death and enhanced resistance to both bacterial and fungal pathogens. Transgen Res 12:577586.

Keller H, Pamboukdjian N, Ponchet M, Poupet A, Delon R, Verrier JL, Roby D, Ricci P (1999). Pathogen induced elicitin production in transgenic tobacco generates a hypersensitive response and non specific disease resistance. Plant Cell 11:223-235.

Kern MF, Maraschin SDF, Endt DV, Schrank A, Vainstein MA, Pasquali G (2010). Expression of a chitinase gene from Metarhizium anisopliae in tobacco plants confers resistance against Rhizoctonia solani. Appl Biochem Biotechnol160:1933-1946.

Kikkert JR, Ali GS, Wallace PG, Reisch B, Reustle GM (2000). Expression of a fungal chitinase in Vitis vinifera L. 'Merlot' and 'Chardonnay' plants produced by biolistic transformation. Acta Hort 528:297-303.

Kim JF, Beer SV (1998). HrpW of Erwinia amylovora, a new harpin that contains a domain homologous to pectate lyases of a distinct class. J Bacteriol 180:5203-5210.

Kiraly Z, Hornok L (1997). Molecular aspects of plant/ pathogen interactions in relation to novel strategies of breeding for disease resistance. Acta Phytopathol Entomol Hung 32:1-28.

Lauge R, Joosten MH, Haanstra JP, Goodwin PH, Lindhout P, De Wit PJGM (1998). Successful search for a resistance gene in tomato targeted against a virulence factor of a fungal pathogen. Proc Natl Acad Sci USA 95:9014-9018.

Li WL, Faris JD, Chittoor JM, Leach JE, Liu DJ, Chen PD, Gill BS (1999). Genomic mapping of defense response genes in wheat. Theor Appl Genet 98:226-233.

Liang H, Maynard CA, Allen RD, Powell WA (2004). Increased Septoria musiva resistance in transgenic hybrid poplar leaves expressing a wheat oxalate oxidase gene. Plant Mol Biol 45:619-629.

Liu M, Sun ZX, Zhu J, Xu T, Harman GE, Lorito M (2004). Enhancing rice resistance to fungal pathogens by 
156

transformation with cell wall degrading enzyme genes from Trichoderma atroviridae. J Zhejiang Univ Sci 5:133-136.

Lorito M, Scala F (1999). Microbial genes expressed in transgenic plants to improve disease resistance. J Plant Pathol 81:7388.

Lorito M, Harman GE, Hayes CK, Broadway RM, Tronsmo A, Woo SL, Di Pietro A (1993). Chitinolytic enzymes produced by Trichoderma harzianum: antifungal activity of purified endochitinase and chitobiosidase. Phytopathol 83:302-307.

Lorito M, Woo SL, Garcia I, Colucci G, Harman GE, PintorToro JA, Filippone E, Muccifora S, Lawrence CB, Zoina A, Tuzun S, Scala F (1998). Genes from mycoparasitic fungi as a source for improving plant resistance to fungal pathogens. Proc Natl Acad Sci USA 95:7860-7865.

Malnoy M, Faize M, Venisse JS, Geider K, Chevreau E (2005) Expression of viral EPS depolymerase reduces fire blight susceptibility in transgenic pear. Plant Cell Rep 23:632638.

Manczinger L, Antal Z, Kredics L (2002). Ecophysiology and breeding of mycoparasitic Trichoderma strains (a review). Acta Microbiol Immunol Hung 49:1-14.

Mauch F, Mauch-Mani B, Boller T (1998). Antifungal hydrolases in pea tissue. II. Inhibition of fungal growth by combinations of chitinase and /3-1,3-glucanase. Plant Physiol 88:936-942.

Meyer V (2008). A small protein that fights fungi: AFP as a new promising antifungal agent of biotechnological value. Appl Microbiol Biotechnol 78:17-28.

Miao W, Wang X, Li M, Song C, Wang Y, Hu D, Wang J (2010). Genetic transformation of cotton with a harpin-encoding gene $h p a_{X_{00}}$ confers an enhanced defense response against different pathogens through a priming mechanism. BMC Plant Biol 10:67-71.

Mina BM, Ciccozzi M, Dimonte S, Farchi F, Aldarchi C, Rezza G, Perno CF, Ciotti M (2008). Identification of the novel KI polyomavirus in the respiratory tract of an Italian patient. J Med Virol 80:2012-2014.

Mora AA, Earle ED (2001). Resistance to Alternaria brassicicola in transgenic broccoli expressing a Trichoderma harzianum endochitinase gene. Mol Breed 8:1-9.

Moreno AB, Penas G, Rufat M, Bravo JM, Estopa M, Messeguer J, Sansegundo B (2005). Pathogen-induced production of the antifungal AFP protein from Aspergillus giganteus confers resistance to the blast fungus Magnaporthe grisea in transgenic rice. Mol Plant-Microbe Interac 18:960-972.

Mourgues F, Brisset M-N, Chevreau E (1998). Strategies to improve plant resistance to bacterial diseases through genetic engineering. Trends Biotechnol 16:203-210.

Muhitch MJ, McCormick SP (2000). Transgenic expression of the TRI101 or PDR5 gene increases resistance of tobacco to the phytotoxic effects of the trichothecene 4,15-diacetoxyscirpenol. Plant Sci 157:201-207.
Niu C, Akasaka-Kennedy Y, Faustinelli P, Joshi M, Rajasekaran K, Yang H, Chu Y, Cary J, Ozias-Akins P (2009). Antifungal activity in transgenic peanut (Arachis hypogaea L.) conferred by a nonheme chloroperoxidase gene. Peanut Sci 36:26-32.

Park CM, Berry JO, Bruenn JA (1996). High level secretion of a virally encoded anti-fungal toxin in transgenic tobacco plants. Plant Mol Biol 30:359-366.

Peng JL, Bao ZL, Ren HY, Wang JS, Dong HS (2004). Expression of Harpin ${ }_{\mathrm{Xoo}}$ in transgenic tobacco induces pathogen defense in the absence of hypersensitive cell death. Phytopathol 94:1048-1055.

Peschen D, Li HP, Fischer R, Kreuzaler F, Liao YC (2004). Fusion poteins comprising a Fusarium specific antibobody linked to antifungal peptides protects plants against a fungal pathogen. Nat Biotechnol 22:732-738.

Qiu D, Mao J, Yang X, Zeng H (2009). Expression of an elicitorencoding gene from Magnaporthe grisea enhances resistance against blast disease in transgenic rice. Plant Cell Rep 28:925-933.

Rajasekaran K, Cary JW, Jacks TJ, Stromberg K, Clevel TE (2000). Inhibition of fungal growth in planta and in vitro by transgenic tobacco expressing a bacterial non heme chloroperoxidase gene. Plant Cell Rep 19:333-338.

Roberts WK, Selitrennikoff CP (1998). Plant and bacterial chitinases differ in antifungal activity. J Gen Microbiol 134:169-176.

Romeis J, Battini M, Bigler F (2003). Transgenic wheat with enhanced fungal resistance causes no effects on Folsomia candida (Collembola: Isotomidae). Pedobiologia 47:141147.

Saiprasad GVS, Mythil JB, Anand L, Suneetha C, Rashmi HJ, Naveena C, Ganeshan G (2009). Development of Trichoderma harzianum endochitinase gene construct conferring antifungal activity in transgenic tobacco. Ind J Biotechnol 8:199-206.

Shao M, Wang J, Dean RA, Lin Y, Gao X, Hu S (2008). Expression of a harpin-encoding gene in rice confers durable nonspecific resistance to Magnaporthe grisea. J Plant Biotechnol 6:73-81.

Shengji M, Hongya G, Lijia Q, Zhangliang C (2003). Obtaining transgenic rice resistant to rice fungal blast disease by controlled cell death strategy. Chin Sci Bullet 48:16-19.

Shetty NP, Lyngs HJ, Jensen JD, Collinge DB, Shetty HS (2008). Roles of reactive oxygen species in interactions between plants and pathogens, Eur J Plant Pathol 121:267280.

Shetty NP, Mehrabi R, Lütken H, Haldrup A, Kema GHJ, Collinge DB (2007). Role of hydrogen peroxide during the interaction between the hemibiotrophic fungal pathogen Septoria tritici and wheat. New Phytol 174:637-647.

Sohn SI, Kim H, Kim BR, Lee SY, Lim CK, Hur JH, Lee JY (2007). Transgenic tobacco expressing the hrpN (EP) gene from Erwinia pyrifoliae triggers defense responses against Botrytis cinerea. Mol Cells 31:232-239. 
Stern R, Asari AA, Sugahara KN (2006). Hyaluronan fragments: an information-rich system. Eur J Cell Biol 85:699-715.

Strittmatter G, Janssens J, Opsomer C, Botterman J (1995). Inhibition of fungal disease development in plants by engineering controlled cell death. Biotechnol 13:10851089.

Suslow TV, Matsubara D, Jones J, Lee R, Dunsmuir P (1988). Effect of expression of bacterial chitinase on tobacco susceptibility to leaf brown spot. Phytopathol 78:15561589.

Takakura Y, Che FS, Ishida Y, Tsutsumi F, Kurotani K, Usami S, Isogai A, Imaseki H (2008). Expression of a bacterial flagellin gene triggers plant immune responses and confers disease resistance in transgenic rice plants. Mol Plant Pathol 9:525-529.

Tepfer D, Boutteaux C, Vigon-Aymes S, Perez V, O’Donohue MJ, Huet JC, Pernollet JC (1998). Phytophthora resistance through production of a fungal protein elicitor (B-cryptogein) in tobacco. Mol Plant Microbe Interac 11:64-67.
Terakawa T, Takaya N, Horiuchi H, Koike M (1997). A fungal chitinase gene from Rhizopus oligosporus confers antifungal activity to transgenic tobacco. Plant Cell Rep 16:439-443.

Toyoda H, Matsuda Y, Yamaga T, Ikeda S, Morita M, Tamai T, Ouchi S (1991). Suppression of the powdery mildew pathogen by chitinase microinjected into barley coleoptile epidermal cells. Plant Cell Rep 10:217-220.

Verberne MC, Verporte R, Bol JF, Mercado-Blanco J, Linthorst HJM (2000). Overproduction of salicylic acid in plants by bacterial transgenes enhances pathogen resistance. Nat Biotechnol 18:779-783.

Wu G, Shortt BJ, Lawrence EB, Fitzsimmons KC, Shah DM (1995). Disease resistance conferred by expression of a gene encoding $\mathrm{H}_{2} \mathrm{O}_{2}$-generating glucose oxidase in transgenic potato plants. Plant Cell 7:1357-1368.

Zasloff M (2002). Antimicrobial peptides of multicellular organisms. Nature 415:389-395.

Zhang H, Li G, Li W, Song F (2009). Transgenic strategies for improving rice disease resistance. Afric J Biotechnol 8:17501757. 